\title{
Evaluation of Good Manufacturing Practices (GMP) and Sanitation Standard Operating Procedure (SSOP) Implementation for Supporting Sustainable Production in Bakery SMEs
}

\author{
Sucipto Sucipto ${ }^{1,2, a, *}$, Petri Wani Sumbayak ${ }^{1, b}$, Claudia Gadizza Perdani ${ }^{1,2, c}$ \\ ${ }^{1}$ Department of Agroindustrial Technology, Faculty of Agricultural Technology, Universitas Brawijaya, Jl. Veteran, Malang, 65145, \\ Indonesia \\ ${ }^{2}$ Halal and Qualified Industry Development (HAL-Q ID), Universitas Brawijaya,Jl. Veteran, Malang, 65145, Indonesia.
}

${ }^{*}$ Corresponding author

\begin{tabular}{|c|c|}
\hline ARTICLE INFO & A B S T R A C T \\
\hline $\begin{array}{l}\text { Keywords: } \\
\text { GMP } \\
\text { Bread } \\
\text { SMEs } \\
\text { SSOP } \\
\text { Sustainable }\end{array}$ & $\begin{array}{l}\text { Resources efficiency in production is essential to support sustainable production. "X" Bakery is one } \\
\text { of the bread small and medium enterprises (SMEs) in Batu, East Java Indonesia. This study aimed } \\
\text { to evaluate the implementation of Good Manufacturing Practices (GMP) and Sanitation Standard } \\
\text { Operating Procedure (SSOP) in bread processing of SMEs production. This research used } \\
\text { observation methods, interviews, and questionnaires. Respondents in this research are supervisors } \\
\text { and employees of "X" Bakery. The results of this study indicated that the GMP implementation } \\
\text { achieved } 58.3 \% \text { and SSOP of } 52.3 \% \text {, implying this industry had been standing under a minimum of } \\
60 \% \text {. This industry had poor qualified of GMP and SSOP. Five aspects of GMP have be fulfilled, } \\
\text { namely the location and environment, production equipment, process control, food labelling, and } \\
\text { product recall. Although, nine elements that have not met, namely buildings and facilities, water } \\
\text { supply, sanitation facilities and activities, pest control, employee health, storage, supervision by the } \\
\text { responsible person, employee documentation, and training. Furthermore, three aspects of SSOP have } \\
\text { met, namely the prevention of cross-contamination, food protection, and labelling. There are five } \\
\text { elements have not fulfilled SSOP criterias, namely the security of water, surface hygiene, sanitation } \\
\text { facilities, and employee health control and pest prevention. The weakest indicator for each GMP and } \\
\text { SSOP implementation are supervision and employee's health control respectively. Therefore, it was } \\
\text { necessary to increase the employee's knowledge, the addition of supporting facilities, and production } \\
\text { supervision to improve the implementation of GMP, SSOP, and sustainable production. }\end{array}$ \\
\hline
\end{tabular}

\section{Introduction}

The growth of the food industry in Indonesia reached $7.70 \%$ quarterly. Its growth must be sustainable following the availability of resources, so it does not threaten the industrial production process in the future. In 2016, there were 976 cases of outbreaks, 2 cases of environmental pollution, and 30 cases of outbreaks by household processed food (BPS, 2017). One of the foods that contribute to outbreaks is bread, especially in bread SMEs.

Resources need to be used efficiently to support sustainable production. According to Toner (2010), sustainable production is the production that focuses on public policies and public interests. "X" bakery in Batu City of East Java has not fully implemented sustainable production yet. Product quality is the first factor that has effects on a decision about purchasing the product (Maric et al., 2009). Canja et al. (2013) said that hygiene rules have to be respectful in the bread industry. Fellows et al. (1995) said quality assurance is vital for small-scale rural food industries. There stand up the good manufacturing practice (GMP) rules to support baking production.

Therefore, it is necessary to evaluate the GMP and Sanitation Standard Operating Procedure (SSOP) to ensure bread safety. GMP should be applied in the food industry to produce safe, proper, and qualified food products. SSOP is used to help achieve the industry's primary goal of creating high-quality, secure, and orderly food (Anggraini and Yudhastuti, 2014). This study aims to evaluate the implementation of GMP and SSOP on " $\mathrm{X}$ " bakery, as well as to provide improvement that supports sustainable production. 


\section{Materials and Methods}

This research was conducted in " $X$ " bakery in Batu City, East Java, Indonesia as a developing country. Analyzing data was held at the Agroindustrial Management Laboratory of Universitas Brawijaya.

\section{Data Collection Technique}

Data were obtained through observation, interview, analysis of documents, and assessment of its implementation. The inspection was conducted in the production area. Interviews were conducted with production employees, production supervisor, and the owner. Analyzing of GMP and SSOP documents. Assessment of GMP and SSOP implementation with scoring by production employees, supervisor, and researcher. The number of employees selected is 15 people from 45 employees.

\section{Data Analysis}

There are fourteen indicators to measure the GMP application based on Indonesia National Agency of Drug and Food Control (INADFC) number 03.1.23.04.12.2207 (2012), namely; 1 . the site and the production environment has a score; 2 . the building and facility; 3 . the production equipment; 4. the water supply or water supply facilities; 5. facilities, hygiene and sanitation; 6. pest control; 7 . health and hygiene employee; 8 . Process control; 9. food label; 10. Storage; 11 . supervision by a responsible person; 12. product withdrawal; 13. documentation and the listing; and 14 the training.

In the other hand, there are eight criteria in the implementation of SSOP, namely; 1. the water security section; 2. the surface cleanliness in contact with the food; 3 . the prevention of cross-contamination; 4. sanitary facilities; 5. the protection of foodstuff from the contaminant; 6 . the labeling of the use of poison materials and proper storage; 7. employee health control; 8. Pest prevention.

The assessment was conducted using Questionnaire were scored as 0 (no application), 1 (less fulfilled), 2 (need improvement), 3 (fulfilled), and 4 (very fulfilled). Percentage scale of application is divided into 6 parts, include $<50 \%$ (not satisfied), 50-59.9\% (enough to meet), 60-79.9\% (complied), 80-89.9\% (conditional), 90-94.9\% (very fulfilling), and $95-100 \%$ (perfect). All the questionnaire output was then converted to the percentage based on the scale above. Finnally, the converted percentage was then described using descriptive statistics form respondents 15 employees, supervisor, and researcher assessment.

\section{Results and Discussion}

\section{Overview " $X$ " bakery}

" $X$ " bakery is a home industry with a workforce of 45 people. The products consist of sweetened cream ball bread (roti mains cream ball), great special torn bread (roti sobek istimewa besar), small special torn bread (roti sobek istimewa kecil), torn comb bread (roti sobek sisir), rolls bread (roti kepang), comb bread (roti sisir), super block bread (roti balok super), special loaf (roti tawar istimewa), leathery cuts loaf (roti tawar potong kulit), lean cut loaf (roti tawar potong tanpa kulit), casino loaf (roti tawar casino), milk loaf (roti tawar susu), and pandan loaf (roti tawar pandan). Examples of products are shown in Figure 1.

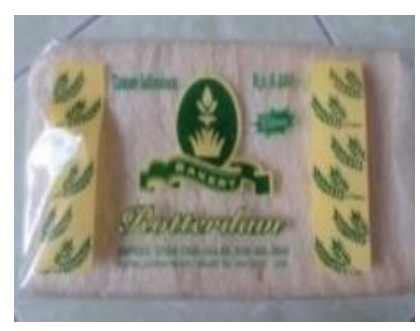

(a)

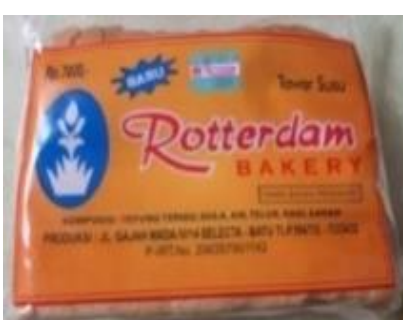

(b)

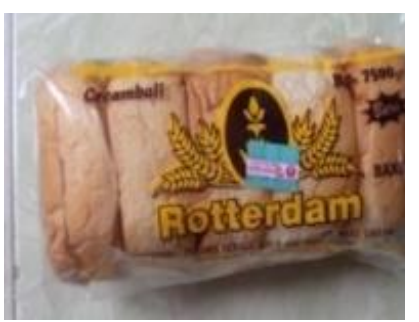

(c)

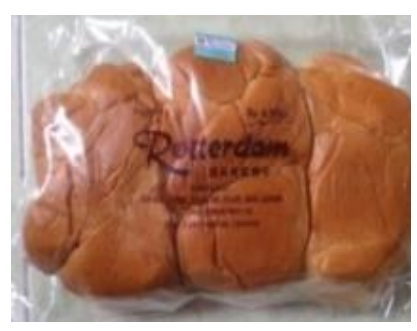

(d)

Figure 1. Examples of products in "X" bakery: (a) Special bar bread (b) milk loaf (c) Sweetened cream ball bread (d) Rolls bread

\section{Implementation of GMP}

The results of the assessment with the application of the GMP method in Table 1. Table 1 shows the average total application of GMP of $58.3 \%$ under the minimum standard of $60 \%$. The results of the assessment, according to the supervisor, have been moderately sufficient, but the evaluation according to the employees, has not fulfilled. This condition indicated that the GMP system had not been fully applied to the ' $\mathrm{X}$ ' bakery. There was an assessment difference between supervisor and employee. This assessment difference is related to the level of knowledge of each employee. This problem can be solved with excellent communication between employees and superiors to generate the same perceptions.
Storage of raw materials, products, and hazardous materials (non-production) were separated. Storage space is cleaned daily to ensure the quality of and maintain the material condition. Temperature and humidity were adjusted following the properties of the material. Supervision has not been done specifically by the head of the production. According to (Rotaru et al., 2005), surveillance should be conducted to ensure quality products and performed by the authorities. Qualification of the supervisor should include understanding the standard production, being able to inspect the process, maintain, check, and calibrate the measuring and monitoring devices. 
Table 1. Value of GMP Implementation on "X" bakery

\begin{tabular}{cl|cccc}
\hline \multirow{2}{*}{ No Scope } & \multicolumn{3}{|c}{ GMP Implementation Assessment (\%) } & \multirow{2}{*}{ Average } \\
\cline { 3 - 5 } & & Employees & Supervisor & Researcher & \\
\hline 1 & Location and Environment & 66.8 & 67.5 & 70.0 & 68.1 \\
2 & Building and Facilities & 59.5 & 62.5 & 57.5 & 59.8 \\
3 & Production Equipment & 66.8 & 75.0 & 67.5 & 69.8 \\
4 & Water Supply or Water Supply Facility & 50.0 & 70.0 & 57.5 & 59.2 \\
5 & Hygiene \& Sanitation Facilities and Activities & 34.5 & 65.0 & 42.5 & 47.3 \\
6 & Pest Control & 41.8 & 62.5 & 37.5 & 47.3 \\
7 & Health and Employee Hygiene & 52.3 & 62.5 & 45.0 & 53.3 \\
8 & Process Control & 64.0 & 65.0 & 65.0 & 64.7 \\
9 & Food Labeling & 66.8 & 67.5 & 67.5 & 67.3 \\
10 & Storage & 55.0 & 60.0 & 55.0 & 56.7 \\
11 & Supervision by Responsible & 37.5 & 35.0 & 37.5 & 36.7 \\
12 & Product Withdrawal & 75.0 & 80.0 & 75.0 & 76.7 \\
13 & Documentation and Recording & 50.0 & 52.5 & 50.0 & 50.8 \\
14 & Employee Training & 62.5 & 50.0 & 57.5 & 56.7 \\
\hline Total Implementation of GMP & 55.7 & 63.1 & 56.1 & 58.3 \\
\hline
\end{tabular}

Standard Operating Procedure (SOP) production had not been written, so the burning of materials based on the habit during the production. This bakery business had already hold SME food safety documents and halal certification. Documentation was carried out to design a detailed picture of what a manufacturing function has to do in the future (Patel and Chotai, 2011). Recording in this business had not been maximizing. Hence problems may potentially arise during production in food SMEs.

Hasnan et al. (2014) said that the SME reasons have an obstacle in implementing GMP is inadequate its infrastructure and facilities. In this research, building facilities have a score of 59.8 and hygiene \& sanitation facilities and activities have a value of 47.3. In low-income countries, food industry was dominated by informal sector that operates outside of regulatory control (Hoffman, Moser, and Saak, 2019). This condition needs improvement to ensure food safety.

SMEs are business have problems due to lack of knowledge and actual know-how (Talib et al., 2013). The employee's training in this bakery was not conducted yet. This training is essential to improve the employee's knowledge to appropriately a good in output. Intensive training should be offered to staff regularly to achieve the objectives (Boadu et al., 2014).

\section{Implementation of SSOP}

The result of the SSOP assessment in ' $\mathrm{X}$ ' bakery is shown in Table 2. Foodstuffs should be protected from contamination, so product quality is well. The control is exerted through preservation and processing, which eliminates microorganisms or prevent their growth (Begani et al., 2012).

The result of the SSOP assessment of 52.3\% had under the minimum standard of $60 \%$. In general, the evaluation of SSOP showed that the system had not run well. Periodically testing of water quality had not been implemented by this small bakery. Untreated water from mountains was considered feasible for consumption. According to Cabral (2010), water quality for food processing is similar for drinking. The minimum water quality check should be done twice per year.

Sanitation facilities in this small bakery industry are not adequate, so it has a score of 39.3. Investigation for sanitation facilities in the research place was not enough. Hoffman, Moser, and Saak (2019) said in the middleincome countries, the lack of incentives to invest in food safety. This condition causes the hygiene of food production is not correctly. Yongmin B (2004) said food safety in China had severe problems, especially in small industries.

Table 2. SSOP Implementation Value on "X" bakery

\begin{tabular}{cl|cccc}
\hline \multirow{2}{*}{ No Scope } & \multicolumn{3}{|c}{ SSOP Implementation Assessment (\%) } & \multirow{2}{*}{ Average } \\
\cline { 3 - 5 } & & Employees & Supervisor & Researcher & \\
\hline 1 & Water safety & 30.0 & 45.0 & 30.0 & 35.0 \\
2 & Hygiene of food contact surface & 55.0 & 62.5 & 37.5 & 46.0 \\
3 & Prevention of cross contamination & 25.3 & 70.0 & 65.0 & 63.4 \\
4 & Sanitation facilities & 82.7 & 50.0 & 42.5 & 39.3 \\
5 & Protection of food from contaminants & 75.0 & 75.5 & 67.5 & 72.6 \\
6 & Labelling and storage of toxic materials & 25.0 & 50.0 & 75.0 & 75.0 \\
7 & Employee health control & 37.3 & 57.5 & 37.5 & 37.5 \\
8 & Pest control & 46.9 & 60.0 & 49.9 & 52.3 \\
\hline Total implementation of SSOP & & & \\
\hline
\end{tabular}


Table 3. Proposed Improvement of GMP Applications in " $\mathrm{X}$ ” Bakery

\begin{tabular}{|c|c|c|}
\hline No & GMP Aspects & Proposed Improvements \\
\hline 1 & Building and facilities & $\begin{array}{l}\text { - The facility layout should be arranged to improve production flow (the } \\
\text { type of process layout). Providing trash can lid, duster in production space, } \\
\text { maintaining the cleanliness of floors, walls, roofs, windows, and lighting } \\
\text { - Complete of window cover, the lamp power is meet production room }\end{array}$ \\
\hline 2 & $\begin{array}{l}\text { Water supply or water } \\
\text { supply facilities }\end{array}$ & $\begin{array}{l}\text { - Water samples should be checked for safety in the laboratory } \\
\text { - Pipe flow of water from the source should be distinguished according to } \\
\text { their function }\end{array}$ \\
\hline 3 & $\begin{array}{l}\text { Hygiene and sanitation } \\
\text { facilities and activities }\end{array}$ & $\begin{array}{l}\text { - Waste should be treated before it is transferred to the environment } \\
\text { - Adding sanitation facilities, such as sink, toilet, employee hygiene } \\
\text { supplies in the production room. } \\
\text { Make writing or symbols to maintain hygiene, such as washing hands, } \\
\text { close the shower, and use a sanitary appliance. }\end{array}$ \\
\hline 4 & Pest control & $\begin{array}{l}\text { - Attach a wire gauze on each vent to avoid pests and dirt and provide pest } \\
\text { tentacle in every corner of the room }\end{array}$ \\
\hline 5 & $\begin{array}{l}\text { Health and hygiene of } \\
\text { employees }\end{array}$ & $\begin{array}{l}\text { - } \quad \text { Employee health check at least once a year } \\
\text { - } \quad \text { Provide SOP for production staff }\end{array}$ \\
\hline 6 & Storage & $\begin{array}{l}\text { - } \quad \text { Provide closed storage shelves for raw materials } \\
\text { - Distinguishing between materials and products, using the entry date }\end{array}$ \\
\hline 7 & Supervision & $\begin{array}{l}\text { - Supervision of all production aspects should be conducted, both } \\
\text { production and sanitation } \\
\text { - } \quad \text { Form a team in charge of the internal effort } \\
\text { - }\end{array}$ \\
\hline 8 & Recording and & - Develop SOP for production, maintenance, repair, and cleaning. \\
\hline & & \\
\hline
\end{tabular}

Table 4. Proposed Improvement of SSOP in "X" Bakery

\begin{tabular}{|c|c|c|}
\hline No. & Aspects SSOP & Proposed Improvements \\
\hline \multirow{2}{*}{1} & \multirow{2}{*}{ Water safety } & - $\quad$ Minimal water quality test 2 times a year \\
\hline & & - Subscribing water supplier to obtain the appropriate water quality \\
\hline \multirow{2}{*}{2} & \multirow{2}{*}{$\begin{array}{c}\text { Cleanliness of contact } \\
\text { surface }\end{array}$} & $\begin{array}{l}\text { - Cleanliness test of each equipment, replace equipment regularly and provide } \\
\text { hygiene monitoring checklist and feasibility of the tolls }\end{array}$ \\
\hline & & $\begin{array}{l}\text { - SOP manufactures sanitary washing apparatus with the material, store in a } \\
\text { clean and dry area, and sterilization equipment }\end{array}$ \\
\hline 4 & The sanitary facilities & $\begin{array}{l}\text { - Adding handwashing facilities, dryers, room deodorizers, cleaners such as } \\
\text { broom, mop, broom, and brush the floor and trash, footwear before entering } \\
\text { production room and production clothing }\end{array}$ \\
\hline \multirow{2}{*}{5} & \multirow{2}{*}{$\begin{array}{l}\text { Employee health } \\
\text { control }\end{array}$} & - Employees must be checked regularly, at least once a year. \\
\hline & & - Have a checklist of overall employee health history \\
\hline \multirow{3}{*}{6} & \multirow{3}{*}{ Pests control } & - Close any window that is not covered with wire netting \\
\hline & & - Providing traps as an insect or pest control device \\
\hline & & - $\quad$ Make rules and SOP in the implementation of industrial hygiene. \\
\hline
\end{tabular}

The sweetbread production in " $X$ " bakery can be seen in Figure 2. It is necessary to identify at each production stage of the Sanitation Control Point (SCP) to prevent product contamination. SCP is an activity to identify food sanitation, employees, and associated with all processing facilities (SHAC, 2000). The employees of the bakery had poor knowledge regarding health problems related to occupational hazards and their prevention. Akabanda et al. (2017) said the food safety knowledge of employees influenced to attitudes and practices of institutional foodhandlers. Yossif and Elaal (2012) reported the training program was need employees to improve skills regarding food safety.

The identification of this bread production SCP in " $\mathrm{X}$ " bakery was as follows: a. During the production preparation, it is necessary to distribute the material from storage to the production room. Raw materials need to be placed on the table. b. Mixing using a clean machine and no leftover dough beforehand. c. The slicing tool and knife must be cleaned and free of rust. Employee hygiene needs to be improved to maintain the quality of each product. d. The product must be controlled free of contaminants before packing. Chen, Martinez, and Feng (2019) said understanding and proper food handling practices were sufficient to prevent cross-contamination.

\section{Proposed Improvement of GMP and SSOP Implementation}

Based on the implementation of GMP and SSOP, there are several proposed improvements (Table 3 and Table 4).

The weakest aspect of GMP implementation is supervision by the responsible person of the production 
department. The lowest of SSOP is the employee health control section. Globally, in developing countries, inadequate food safety education was identified as factors that influence food safety (Kaferstein, 2003; Grace, 2015; Vipham et al., 2018).

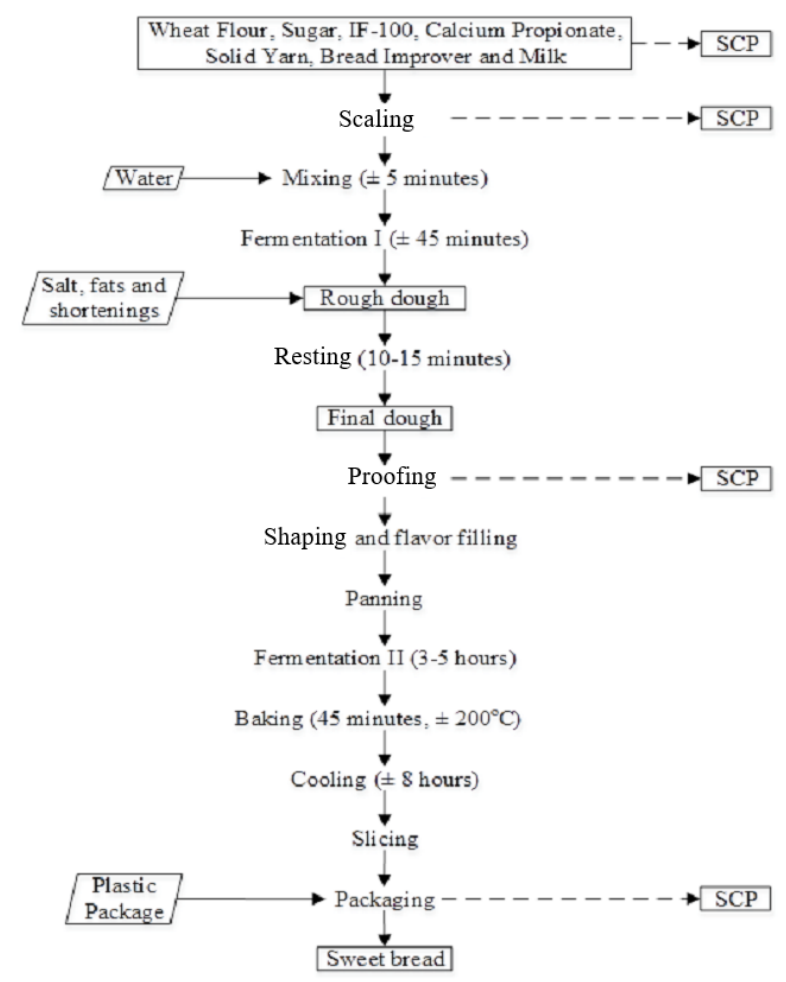

Figure 2. Production Process of Sweet Bread on "X" Bakery. SCP is Sanitation Control Point

Bad culture in the food safety caused lots of food fraud (Jen, 2017). This condition contributes to less pest control and fewer employee's hygiene. Supervision in this small bakery is not adequate, so the supervisor's ability to handle their job needs to be raised. Jen (2017) explained limited qualified inspectors to food handling. Therefore, training programs for employees is impressive. Yossif and Elaal (2012) said there should consider significant differences between before and after the training. Hui (2014) said GMP and SSOP are minimal legal requirements in food processing. Technically activities such as close any window that is not covered with wire netting and providing traps as an insect to prevent insects into the production room must be implemented (Table 4). This section should be emphasized in its application to support the standards of food processing and sustainable production.

\section{Conclusion}

Evaluation of GMP and SSOP in " $\mathrm{X}$ " bakery is as follows. Five aspects of GMP have met the criteria, namely location and environment, production equipment, process control, food labelling, and product recall. Nine elements that have not to meet the requirements, namely buildings and facilities, water supply, sanitation facilities and activities, pest control, employee health, storage, supervision by the responsible person, documentation, and training. Three aspects of SSOP have met the criteria, namely prevention of cross-contamination, protection of food and labelling of toxic reagent and proper storage. Five aspects have not reached the requirements, namely water security, surface cleanliness, sanitation facilities, employee health control, and pest prevention. The weakest of GMP is supervision by the person in charge, while the lowest of SSOP is the employee's health control. The average total applied GMP 58.3\% and SSOP 52.3\%, both of which have not met the minimum standard of $60 \%$. GMP and SSOP implementation are vital for the food industry to support quality and sustainable production. Therefore, necessary to increase employee knowledge, addition of supporting facilities and production monitoring.

\section{References}

Akabanda F, Hlortsi EH, Owusu-Kwarteng J. 2017. Food safety knowledge, attitudes, and practices of institutional foodhandlers in Ghana. BMC Public Health. 17: 40.

Anggraini T, Yudhastuti R. 2014. Penerapan good manufactoring practices pada industri rumah tangga kerupuk teripang di Sukolilo Surabaya. J Kes Ling. 7: 148-158.

Begani RK, Tombe B, Polong T. 2012. Effectiveness of cleaning and sanitation of food contact surfaces in the PNG fish canning industry. Contemporary PNG Studies. 17: 62-68.

Boadu F, Dwomo-Fokuo E, Boakye JK, Kwaning CO. 2014. Training and development: A tool for employee performance in the district assemblies in Ghana. Int J Educ Res. 2: 130146.

BPS. 2017. Pertumbuhan produksi industri manufaktur Triwulan IV-2017, Jakarta: Badan Pusat Statistik.

Cabral J.P. 2010. Water microbiology. Bacterial pathogens and water. Int J Environ Res Public Health. 7: 3657-3703.

Canja C, Enache D, Lupu M, Enache D. 2013. Study on hygiene rules in bakery industry. Computational mechanics and virtual engineering. Romania: COMEC, pp: 377-382.

Chen H, Martinez V, Feng Y. 2020. Food safety education attitude and practice among health professionals in China, Peru, and the U.S. Food Control. 109: 106945. https://doi.org/10.1016/j.foodcont.2019.106945

Fellows P, Axtell BL, Dillon M. 1995. Quality assurance for small-scale rural food industries, Rome: Food \& Agriculture Org. 9251036543

Grace D. 2015. Food safety in developing contries: An overview evidence on demand.

Hasnan NZN, Aziza NAb, Zulkifli N, Taipa FS. 2014. Food factory design: Reality and challenges faced by Malaysian SMEs. Agriculture and Agricultural Science Procedia 2328 - 336. Doi:10.1016/j.aaspro.2014.11.046.

Hoffmann V, Moser C, Saak A. 2019. Food safety in low and middle-income countries: The evidence through an economic lens. World Development 123 (104611): 1-14. Doi:10.1016/j.worlddev.2019.104611.

Hui YH. 2014. Plant Sanitation for Food Processing and Food Service, Florida: CRC Press. 146657769X

Indonesia National Agency of Drug and Food Control (INADFC). 2012. Number 03.1.23.04.12.2207 Certificate Guidelines for Household Food Production Industry. Jakarta

Jen JJ. 2017. Global challenges of food safety for China. Frontiers of Agricultural Science and Engineering. 5(3): 291-293.

Kaferstein F. 2003. Foodborne diseases in developing countries: aetiology, epidemiology and strategies for prevention. Inter. J. of Environ. Reach. 13: 161-168.

Marić A, Arsovski S, Mastilović J. 2009. Contribution to the improvement of product quality in baking industry. Int J Qual Res. 3: 209-216.

Patel K, Chotai N. 2011. Documentation and records: Harmonized GMP requirements. J Young Pharm. 3: 138-150. 
Rotaru G, Sava N, Borda D, Stanciu S. 2005. Food quality and safety management systems: a brief analysis of the individual and integrated approaches. J Agroaliment Processes Technol. 11: $229-236$

SHAC. 2000. Sanitation control procedures for processing fish and fishery products, Florida: Sea Grant, Florida.

Talib HHA, Ali KAM, Idris F. 2013. Quality management framework for the SME's food processing industry in Malaysia. International Food Research Journal 20(1): 147164

Toner G. 2010. Sustainable production: Building Canadian capacity, Canada: UBCPress. 978-0-7748-1251-1
Vipham JL, Chaves BD, Trinetta V. 2018. Mind the gab: How can food safety gaps be addressed in developing nations? Animal Frontiers. 8(4): 16-25.

Yongmin B. 2004. The challenges for food safety in China. Current legislation is unable to protect consumers from the consequences of unscrupulous food production. China Perspectives 53: 1-8. URL: http://journals.openedition.org /chinaperspectives/819. Doi: 10.4000/chinaperspectives.819. Yossif HA, Elaal EMA. 2012. Occupational hazards: Prevention of health problems among bakery workers in Benha City. J Am Sci. 8: 99-108. 